\title{
Effects of psychotropic drugs on canine cerebral metabolism and circulation related to EEG- diazepam, clomipramine, and chlorpromazine
}

\author{
ATSUO SARI ${ }^{1}$, YASUO FUKUDA, TAKEFUMI SAKABE, \\ TSUYOSHI MAEKAWA, AND TOSHIZO ISHIKAWA
}

From the Department of Anesthesiology, Yamaguchi University School of Medicine, Ube, Yamaguchi, Japan

SYNOPSIS The effects of diazepam, clomipramine, and chlorpromazine upon cerebral metabolism and blood flow were examined separately in 18 dogs. After the administration of diazepam or clomipramine, cerebral cortical oxygen consumption $\left(\mathrm{CMR}_{\mathrm{O}_{2}}\right)$ decreased significantly by a maximum of $17 \%$ and $13 \%$ of control within 10 minutes and 15 minutes, and returned to control at $120 \%$ minutes and 90 minutes, respectively. Chlorpromazine, however, decreased by a maximum of $10 \%$ of control, a level which continued throughout the period of observation. It was observed that ${ }^{\circ}$ reduction in $\mathrm{CMR}_{\text {glucose }}$ was followed by the reduction in $\mathrm{CMR}_{\mathrm{O}_{2}}$ at an interval during the early stages of $\mathrm{CMR}_{\mathrm{O}_{2}}$ depression. Diazepam produced a significant decrease in CBF accompanied by ao reduction in $\mathrm{CMR}_{\mathrm{O}_{2}}$, but neither clomipramine nor chlorpromazine had any effect on CBF in spite of reduction in $\mathrm{CMR}_{\mathrm{O}_{2}}$. Reduction in $\mathrm{CMR}_{\mathrm{O}_{2}}$ both with diazepam and clomipramine was accom panied by slow wave activities of EEG, but with chlorpromazine reduction in $\mathrm{CMR}_{\mathrm{O}_{2}}$ was accom-? panied with less pronounced slow wave activities. It was concluded that the three drugs examined were cerebral metabolic depressants.

It has been generally assumed that the effects of psychotropic drugs upon the central nervous system are related to their therapeutic action in patients with psychiatric disorder. This assumption follows from extensive pharmacological, biochemical, and electrophysiological studies obtained with these drugs. In the present study we examined the effect of three psychotropic drugs-diazepam, clomipramine, and chlorpromazine-on the canine cerebral metabolism and circulation.

Although the effects of chlorpromazine on cerebral oxygen consumption have been extensively investigated in animals (Frowein et al., 1955) or men (Fazekas et al., 1955; Morris et al., 1955; Aizawa et al., 1956; Moyer et al., 1956; Ehrmantraut et al., 1957; Sutherland et al.,

1 Address for correspondence and reprints: $\mathrm{Dr}$ A Sari, Department of Anesthesiology, Yamaguchi University, School of Medicine, 1144 Kogushi Ube, Yamaguchi, Japan.

(Accepted 10 March 1975.)
1960), where the other two drugs are concerned, despite their profound effects on the central nervous system, little information has been reported regarding their effect on cerebral metabolism (in vivo) and circulation. It was, therefore, the purpose of the present study to attempt to discover whether or not these drugs produce any changes in cerebral metabolism and circulation related to EEG.

A part of the study on diazepam has been reported elsewhere (Maekawa et al., 1974).

\section{METHODS}

Eighteen fasting unpremedicated dogs weighing 8 to $26 \mathrm{~kg}$ were anaesthetized with halothane $(1.0-2.0 \%)$ inspired in oxygen. The trachea was intubated with a cuffed endotracheal tube with the aid of succinylcholine and thereafter $10 \mathrm{mg} / \mathrm{kg} / \mathrm{h}$ was given to maintain muscle paralysis. Ventilation was controlled with an animal respirator, AR-300 (Acoma, Tokyo, Japan). Cannulae were placed in the femoral artery 
for blood sampling and pressure determination, in one femoral vein for the reinfusion of blood, and in another femoral vein for drug administration. Thereafter, the dog was placed in a prone position with the head supported on a block.

The surgical preparation used in the present study for direct measurement of cerebral blood flow (CBF) was originally described in detail by Michenfelder $\boldsymbol{e t}$ al. (1968). With this technique, blood flow from the sagittal sinus is diverted through a cannula to an external reservoir at the level of the sinus, measured by timed collection, and returned by pump into the femoral vein. The percentage of the drained region was determined by staining the veins with Sudan III dissolved in vinyl acetate monomer injected from the cannulated portion of the sagittal sinus at the completion of the study. These percentages and the individual brain weights of the dogs studied were used to convert unit of flow per minute to per $100 \mathrm{~g}$ of brain weight per minute. After isolation by obliteration of the diploic veins that communicate with the sagittal sinus, the collection and the measurement of the venous drainage of a known portion of the brain provides a ready source for sampling mixed venous blood, which is exclusively representative of the brain tissue.

The oxygen content of arterial and sagittal sinus blood was calculated from measurements of oxyhaemoglobin (IL 182 CO-oximeter, Instrumental Laboratories, Boston, Mass., U.S.A.) and oxygen tension (IL 113 electrodes). Additional measurements included arterial pressure (strain gauge), $\mathrm{pH}$ and $\mathrm{PaCO}_{2}$ (electrode $37^{\circ} \mathrm{C}$ ), and brain temperature (parietal epidural thermistor). Cerebral metabolic rate for oxygen $\left(\mathrm{CMR}_{\mathrm{O}_{2}}\right)$ was calculated as the product of $\mathrm{CBF}$ and arterial sagittal sinus blood oxygen content difference $\left(\mathrm{C}(\mathrm{a}-\mathrm{v}) \mathrm{O}_{2}\right)$. Blood glucose level was determined by an enzymatic method. $\mathrm{CMR}_{\text {glucsse }}$ was calculated as the product of CBF and arterial sagittal sinus blood glucose difference $\left(\mathrm{C}(\mathrm{a}-\mathrm{v})_{\mathrm{glucose}}\right)$. Cerebral vascular resistance (CVR) was calculated as the ratio of the mean arterial pressure (MAP) to the CBF. The oxygen-glucose index (OGI) was calculated as described by Cohen $e t$ al. (1967). The EEG was recorded from the parietal lobes using bipolar silver-silver chloride disc electrodes and was analysed every 10 seconds with a frequency analyser, MAF-5 (Nihonkoden, Tokyo, Japan) throughout the study. Every activity was expressed as a percentage of integrated voltage of $\delta$ $(2-4 \mathrm{~Hz}), \theta(4-8 \mathrm{~Hz}), \alpha(8-13 \mathrm{~Hz}), \beta_{1}(13-20 \mathrm{~Hz})$ and $\beta_{2}(20-30 \mathrm{~Hz})$ waves.

After completion of the surgical preparation, the inspired halothane was maintained at $0.2 \%$ for $1 \mathrm{~h}$ so that any possible effects of residual halothane on $\mathrm{CMR}_{\mathrm{O}_{2}}$, $\mathrm{CBF}$ or EEG could be kept constant
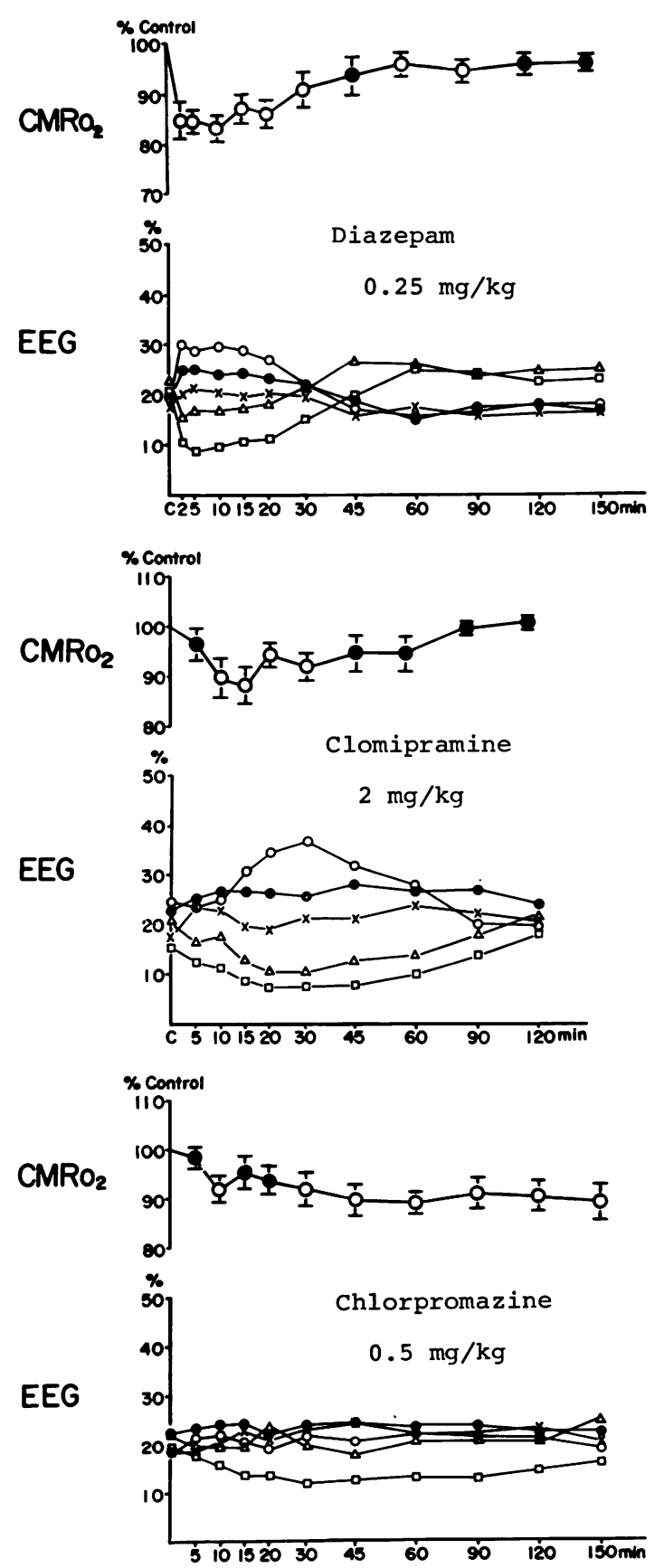

FIG. 1 Effects of diazepam, clomipramine, and chlorpromazine on $C M R_{\mathrm{O}_{2}}$; and each wave activity of EEG. Three figures represent sequential changes in $C M R_{\mathrm{O}_{2}}$; accompanied by changes in the EEG after administration of diazepam, clomipramine, and chlorpromazine. Key: $\bigcirc: \delta$ wave, - : $\theta$ wave, $\times: \alpha$ wave, $\triangle: \beta_{1}$ wave, $\square: \beta_{2}$ wave. 
throughout the study. Ventilation was adjusted to maintain normocapnia $\left(\mathrm{PaCO}_{2} 39 \pm 2 \mathrm{mmHg}\right)$. Sodium bicarbonate was given as needed to maintain a normal buffer base. The epidural temperature was maintained at $37 \pm 0.1^{\circ} \mathrm{C}$ by external means, and haemoglobin levels were maintained above $13 \mathrm{~g} / \mathrm{dl}$. Blood loss due to sampling was replaced by fresh heparinized blood.

Control measurements were obtained over a 30 minute period and mean values were calculated from five to eight consecutive determinations of $\mathrm{CBF}$ and $\mathrm{C}(\mathrm{a}-\mathrm{v}) \mathrm{O}_{2}$ and two to three determinations of $\mathrm{C}(\mathrm{a}-\mathrm{v})_{\mathrm{giucose}}$. The dogs were divided into three groups. Five dogs received $0.25 \mathrm{mg} / \mathrm{kg}$ diazepam, five dogs received $2 \mathrm{mg} / \mathrm{kg}$ clomipramine, and eight dogs received $0.5 \mathrm{mg} / \mathrm{kg}$ chlorpromazine. All drugs were administered intravenously. After control determinations, measurements were done subsequently at $2,5,10,20,30,45,60,90,120$ and 150 (except for clomipramine) minutes after injection of each drug. No evidence of extracerebral contamina- tion of blood or other cerebral vascular anomalies was found at necropsy.

Statistical significance was tested by Student's $t$ test for paired data $(P<0.05$, considered statistically significant).

\section{RESULTS}

The sequential effects of diazepam, clomipramine, and chlorpromazine upon cerebral haemodynamics, metabolism, and EEG are shown in Tables 1, 2, and 3, and Fig. 1.

CEREBRAL METABOLISM Two minutes after the administration of $0.25 \mathrm{mg} / \mathrm{kg}$ diazepam, $\mathrm{CMR}_{\mathrm{O}_{2}}$ was reduced significantly and remained decreased over a 90 minute period. Thereafter, it returned to control value. Its minimum level was $84 \%$ of control at 10 minutes. OGI at two minutes decreased significantly to $77 \%$.

TABLE 1

EFFECTS OF DIAZEPAM (0.25 MG/KG) ON CEREBRAL METABOLISM AND CIRCULATION

\begin{tabular}{|c|c|c|c|c|c|c|c|c|c|c|c|c|c|c|c|c|}
\hline \multirow[t]{2}{*}{$\begin{array}{l}\text { Time } \\
(\min )\end{array}$} & \multicolumn{2}{|c|}{$\begin{array}{c}C M R_{\mathrm{O}_{2}} \\
(\mathrm{ml} / 100 \mathrm{~g} / \mathrm{min})\end{array}$} & \multicolumn{2}{|c|}{$\begin{array}{c}\text { CMRglucose } \\
(\mathrm{mg} / 100 \mathrm{~g} / \mathrm{min})\end{array}$} & \multicolumn{2}{|c|}{$\begin{array}{l}O G I \\
(\%)\end{array}$} & \multicolumn{2}{|c|}{$\begin{array}{c}C B F \\
(\mathrm{ml} / 100 \mathrm{~g} / \mathrm{min})\end{array}$} & \multicolumn{2}{|c|}{$\begin{array}{c}M A P \\
(m m H g)\end{array}$} & \multicolumn{2}{|c|}{$\begin{array}{c}C V R \\
(m m H g / m l \mid \\
100 \mathrm{~g} / \mathrm{min})\end{array}$} & \multicolumn{2}{|c|}{$\begin{array}{r}\mathrm{PaCO}_{2} \\
(\mathrm{mmHg})\end{array}$} & \multicolumn{2}{|c|}{$\begin{array}{c}\mathrm{PssO}_{2} \\
(\mathrm{mmHg})\end{array}$} \\
\hline & Mean & $S E$ & Mean & $S E$ & Mean & $S E$ & Mean & $S E$ & Mean & $S E$ & Mean & $S E$ & Mean & $S E$ & Mean & $S E$ \\
\hline Control & 6.3 & 0.4 & 9.1 & 0.6 & 96 & 4 & 60 & 2 & 110 & 9 & 1.85 & 0.19 & 40.8 & 1.5 & 34 & 2 \\
\hline 2 & 5.3 & $0.4^{*}$ & 9.4 & 1.2 & 77 & $5 *$ & 51 & $10^{*}$ & 98 & 12 & 1.94 & 0.25 & 41.8 & 1.3 & 33 & 1 \\
\hline 10 & 5.2 & $0.4^{*}$ & 7.4 & $0.6^{*}$ & 100 & 5 & 53 & $2 *$ & 101 & 10 & 1.94 & 0.25 & NE & NE & 33 & 1 \\
\hline 30 & 5.7 & $0.4^{*}$ & 7.9 & 1.0 & 99 & 6 & 54 & 3 & 103 & 9 & 1.98 & 0.26 & NE & NE & 32 & 3 \\
\hline 90 & 5.9 & $0.4^{*}$ & 9.6 & 1.2 & 87 & 9 & 55 & 3 & 114 & 8 & 2.14 & 0.24 & 39.3 & 1.8 & 29 & 3 \\
\hline 150 & 6.1 & 0.4 & 8.8 & 0.7 & 93 & 5 & 57 & 4 & 110 & 7 & 1.99 & 0.23 & 39.1 & 1.9 & 30 & 3 \\
\hline
\end{tabular}

* Significantly different from control $(P<0.05)$. NE = not examined.

TABLE 2

EFFECTS OF CLOMIPRAMINE ( 2 MG/KG) ON CEREBRAL METABOLISM AND CIRCULATION

\begin{tabular}{|c|c|c|c|c|c|c|c|c|c|c|c|c|c|c|c|c|}
\hline \multirow[t]{2}{*}{$\begin{array}{l}\text { Time } \\
(\min )\end{array}$} & \multicolumn{2}{|c|}{$\begin{array}{c}C M R_{\mathrm{O}_{2}} \\
(\mathrm{ml} / 100 \mathrm{~g} / \mathrm{min})\end{array}$} & \multicolumn{2}{|c|}{$\begin{array}{c}\text { CMRglucose } \\
(\mathrm{mg} / 100 \mathrm{~g} / \mathrm{min})\end{array}$} & \multicolumn{2}{|c|}{$\begin{array}{l}O G I \\
(\%)\end{array}$} & \multicolumn{2}{|c|}{$\begin{array}{c}C B F \\
(\mathrm{ml} / 100 \mathrm{~g} / \mathrm{min})\end{array}$} & \multicolumn{2}{|c|}{$\begin{array}{c}M A P \\
(m m H g)\end{array}$} & \multicolumn{2}{|c|}{$\begin{array}{c}C V R \\
(\mathrm{mmHg} / \mathrm{ml} / \\
100 \mathrm{~g} / \mathrm{min})\end{array}$} & \multicolumn{2}{|c|}{$\begin{array}{c}\mathrm{PaCO}_{2} \\
(\mathrm{mmHg})\end{array}$} & \multicolumn{2}{|c|}{$\begin{array}{c}\mathrm{PssO}_{2} \\
(\mathrm{mmHg})\end{array}$} \\
\hline & Mean & $S E$ & Mean & $S E$ & Mean & $S E$ & Mean & $S E$ & Mean & $S E$ & Mean & $S E$ & Mean & $S E$ & Mcan & $S E$ \\
\hline $\begin{array}{c}\text { Control } \\
5 \\
10 \\
15 \\
30 \\
60 \\
120\end{array}$ & $\begin{array}{l}6.4 \\
6.3 \\
5.8 \\
5.6 \\
5.9 \\
6.1 \\
6.5\end{array}$ & $\begin{array}{l}0.2 \\
0.4 \\
0.3^{*} \\
0.4^{*} \\
0.3^{*} \\
0.4 \\
0.2\end{array}$ & $\begin{array}{l}9.1 \\
9.3 \\
9.4 \\
9.6 \\
8.5 \\
9.3 \\
9.1\end{array}$ & $\begin{array}{l}0.3 \\
0.5 \\
0.6 \\
0.6 \\
0.6 \\
0.6 \\
0.5\end{array}$ & $\begin{array}{l}95 \\
90 \\
84 \\
80 \\
95 \\
88 \\
97\end{array}$ & $\begin{array}{l}4 \\
3 \\
6^{*} \\
4^{*} \\
8 \\
6 \\
3\end{array}$ & $\begin{array}{l}58 \\
59 \\
55 \\
53 \\
54 \\
57 \\
57\end{array}$ & $\begin{array}{l}2 \\
4 \\
4 \\
4 \\
3 \\
3 \\
3\end{array}$ & $\begin{array}{r}123 \\
112 \\
96 \\
79 \\
83 \\
106 \\
115\end{array}$ & $\begin{array}{c}9 \\
13 \\
11^{*} \\
12^{*} \\
13^{*} \\
10 \\
8\end{array}$ & $\begin{array}{l}2.17 \\
1.98 \\
1.78 \\
1.53 \\
1.56 \\
1.88 \\
2.04\end{array}$ & $\begin{array}{l}0.21 \\
0.32 \\
0.25^{*} \\
0.22^{*} \\
0.22^{*} \\
0.17 \\
0.19\end{array}$ & $\begin{array}{l}37.6 \\
38.1 \\
37.6 \\
38.7 \\
38.4 \\
38.2 \\
39.2\end{array}$ & $\begin{array}{l}0.9 \\
0.4 \\
0.4 \\
0.5 \\
0.4 \\
0.4 \\
1.1\end{array}$ & $\begin{array}{l}34 \\
34 \\
33 \\
33 \\
32 \\
32 \\
31\end{array}$ & $\begin{array}{l}2 \\
2 \\
3 \\
4 \\
4 \\
3 \\
2 \\
2\end{array}$ \\
\hline
\end{tabular}

* Significantly different from control $(P<0.05)$ 
TABLE 3

EFFECTS OF CHLORPROMAZINE ( 0.5 MG/KG) ON CEREBRAL METABOLISM AND CIRCULATION

\begin{tabular}{|c|c|c|c|c|c|c|c|c|c|c|c|c|c|c|c|c|}
\hline \multirow[t]{2}{*}{$\begin{array}{l}\text { Time } \\
(\min )\end{array}$} & \multicolumn{2}{|c|}{$\begin{array}{c}C M R_{\mathrm{O}_{2}} \\
(m l / 100 \mathrm{~g} / \mathrm{min})\end{array}$} & \multicolumn{2}{|c|}{$\begin{array}{c}\text { CMRglucose } \\
(\mathrm{mg} / 100 \mathrm{~g} / \mathrm{min})\end{array}$} & \multicolumn{2}{|c|}{$\begin{array}{l}O G I \\
(\%)\end{array}$} & \multicolumn{2}{|c|}{$\begin{array}{c}C B F \\
(\mathrm{ml} / \mathrm{lOOg} / \mathrm{min})\end{array}$} & \multicolumn{2}{|c|}{$\begin{array}{c}M A P \\
(m m H g)\end{array}$} & \multicolumn{2}{|c|}{$\begin{array}{c}C V R \\
(\mathrm{mmHg} / \mathrm{ml} / \\
100 \mathrm{~g} / \mathrm{min})\end{array}$} & \multicolumn{2}{|c|}{$\begin{array}{c}\mathrm{PaCO}_{2} \\
(\mathrm{~mm} \mathrm{Hg})\end{array}$} & \multicolumn{2}{|c|}{$\begin{array}{c}\mathrm{PssO}_{2} \\
(\mathrm{~mm} \mathrm{mg})\end{array}$} \\
\hline & Mean & $S E$ & Mean & $S E$ & Mean & $S E$ & Mean & $S E$ & Mean & $S E$ & Mean & $S E$ & Mean & $S E$ & Mean & $S E$ \\
\hline Control & 6.3 & 0.1 & 8.8 & 0.3 & 97 & 2 & 60 & 3 & 94 & 6 & 1.57 & 0.07 & 39.2 & 0.7 & 35 & 2 \\
\hline 5 & 6.3 & 0.1 & 11.5 & $1.0^{*}$ & 73 & $5^{*}$ & 58 & 3 & 90 & 6 & 1.56 & 0.10 & 39.5 & 0.7 & 34 & 2 \\
\hline 10 & 5.8 & $0.2^{*}$ & 9.8 & 0.7 & 82 & 6 & 59 & 3 & 84 & $6^{*}$ & 1.46 & 0.08 & 39.6 & 0.6 & 34 & 3 \\
\hline 30 & 5.8 & $0.2^{*}$ & 8.8 & 0.3 & 89 & 3 & 57 & 2 & 77 & $5^{*}$ & 1.33 & $0.09^{*}$ & 40.0 & 0.8 & 32 & 3 \\
\hline 90 & 5.8 & $0.2^{*}$ & 8.4 & 0.4 & 93 & 4 & 53 & 2 & 74 & $4^{*}$ & 1.42 & 0.12 & 39.9 & 1.3 & 28 & 2 \\
\hline 150 & 5.6 & $0.2^{*}$ & 8.0 & 0.3 & 93 & 5 & 49 & 3 & 70 & $6^{*}$ & 1.45 & 0.15 & 38.6 & 0.7 & 26 & 2 \\
\hline
\end{tabular}

* Significantly different from control $(\mathrm{P}<0.05)$

A significant reduction in $\mathrm{CMR}_{\mathrm{O}_{2}}$ was observed between 10 and 30 minutes after administration of $2 \mathrm{mg} / \mathrm{kg}$ clomipramine. And thereafter $\mathrm{CMR}_{\mathrm{O}_{2}}$ gradually returned to control value during 45 to 120 minutes. The minimum level in $\mathrm{CMR}_{\mathrm{O}_{2}}$ in the clomipramine group was $87 \%$ of control at 15 minutes after the injection. There were no significant changes in $\mathrm{CMR}_{\text {glucose. The }}$ OGI showed a transient significant decrease between 10 to 15 minutes, and thereafter returned to control. With $0.5 \mathrm{mg} / \mathrm{kg}$ chlorpromazine, $\mathrm{CMR}_{\mathrm{O}_{2}}$ decreased significantly to $92 \%$ of control 10 minutes after injection and continued to decrease throughout a 150 minute period of observation. At five minutes, chlorpromazine briefly, but significantly, caused an increase of $\mathrm{CMR}_{\text {glucose }}$ while not significantly decreasing $\mathrm{CMR}_{\mathrm{O}_{2}}$. As a result, a significant reduction in OGI occurred.

CEREBRAL HAEMODYNAMICS A statistically significant reduction in $\mathrm{CBF}$ was produced at two and 10 minutes in the diazepam group, but was not accompanied by significant changes in MAP or CVR. In each group that was given clomipramine or chlorpromazine, MAP started to decrease significantly at 10 minutes with a concomitant reduction in CVR and gradually returned to control value within 60 minutes in the clomipramine group, but continued to decrease throughout the period observed in the chlorpromazine group. There were no significant changes in $\mathrm{CBF}$ in the two groups, which indicates that $\mathrm{CBF}$ was maintained by a significant reduction in CVR accompanied by a considerable fall in MAP. No significant changes in
$\mathrm{PaCO}_{2}$ or sagittal sinus $\mathrm{PO}_{2}\left(\mathrm{PssO}_{2}\right)$ were observed during the period of observation in all groups after the administration of each drug.

EEG AND $\mathrm{CMR}_{\mathrm{O}_{2}}$ Representative EEG changes and corresponding values of $\mathrm{CMR}_{\mathrm{O}_{2}}$ of the three groups are illustrated in Figs 2, 3, and 4. With diazepam, high voltage $(100-150 \mu \mathrm{V})$ slow

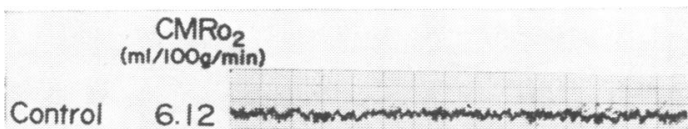

Diazepam $(0.25 \mathrm{mg} / \mathrm{kg})$

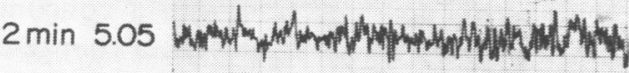

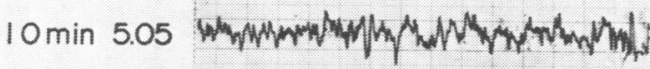

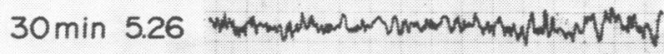

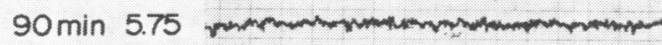
$150 \min 6.06$ $\frac{11}{18}^{\text {souv }}$

FIG. 2 A typical EEG tracing before and after injection of diazepam with corresponding values of $\mathrm{CMR}_{\mathrm{O}_{2}}$. 


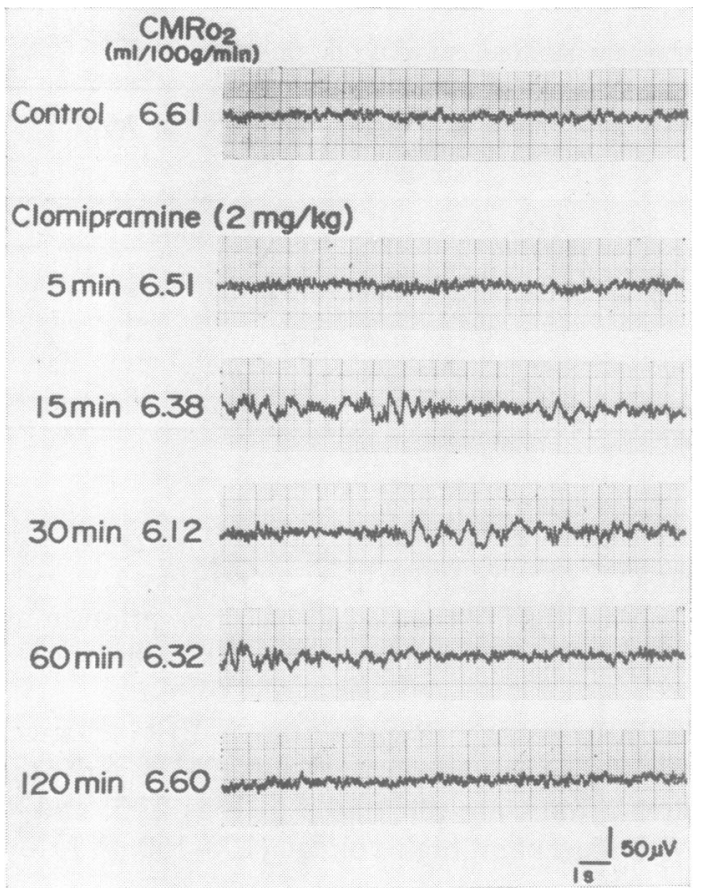

FIG. 3 A typical EEG tracing before and after injection of clomipramine with corresponding values of $C M R_{\mathrm{O}_{2}}$.

wave activity $(\delta)$ predominated within two minutes after the injection with a concomitant decrease in fast waves. These EEG changes were statistically significant and thereafter gradually returned to control levels over a 20 to 30 minute period. Such predominant increases in slow wave activity corresponded with the decreases in $\mathrm{CMR}_{\mathrm{O}_{2}}$ (Fig. 2). With clomipramine, slow wave $(\delta)$ activities showed a tendency to increase, and fast wave activities decreased within five minutes after injection and reached their lowest value within 15 to 30 minutes, corresponding to a reduction in $\mathrm{CMR}_{\mathrm{O}_{2}}$ (Fig. 3). These EEG changes with clomipramine gradually returned to control levels within 90 to 120 minutes after injection. Chlorpromazine showed different EEG changes from the two former drugs; significant increases in $\delta$ and $\alpha$ wave activities were observed from 30 minutes and 10 minutes after injection, respectively, accompanied by a significant reduction in $\beta_{2}$ waves (Fig. 4).

\section{$\mathrm{CMRO}_{2}$

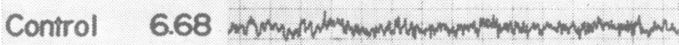

\section{Chlorpromazine $(0.5 \mathrm{mg} / \mathrm{kg})$}

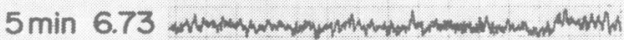

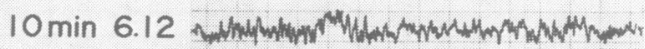

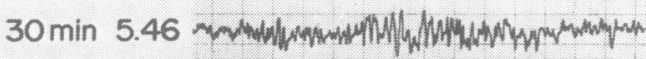

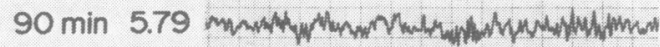

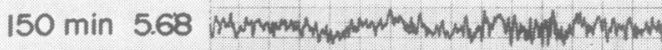

- $\operatorname{son} \mu \mathrm{iv}$

FIG. 4 A typical EEG tracing before and after injec tion of chlorpromazine with corresponding values of $C M R_{\mathrm{O}_{2}}$.

\section{DISCUSSION}

In dosage similar to that used in clinical practice, diazepam, clomipramine, and chlorpromazine cause a significant reduction in $\mathrm{CMR}_{\mathrm{O}_{2}}$ in dogs.

Reduction in $\mathrm{CMR}_{\mathrm{O}_{2}}$ with diazepam accompanied by a concomitant reduction in CBF occurred within two minutes after the injection. The appearance of the effect of diazepam on $\mathrm{CMR}_{\mathrm{O}_{2}}$ was faster than either clomipramine or chlorpromazine, which possibly indicates that diazepam can pass the blood-brain barrier faster than the other two. This is in agreement with findings reported by Kleijn (1969) that uptake of $\left[{ }^{14} \mathrm{C}\right]$ diazepam in the mouse brain reaches its maximum about one minute after intravenous injection. In vitro, Davis et al. (1971) demonstrated a reduction in oxygen consumption in rat brain mitochondria.

There has been no available report concerning 
the effect of clomipramine or other types of antidepressant drugs on cerebral oxygen consumption in vivo. However, in vitro, Ernsting et al. (1960) investigated the effect of several psychotropic drugs on the oxygen consumption in rat brain and concluded that imipramine reduced oxygen consumption significantly. Di Mascio et al. (1964) found the tricyclic antidepressants, imipramine or desipramine, produced hypnotic-like action in normal men. The present study indicated that their hypnotic-like action may be related to decrease in $\mathrm{CMR}_{\mathrm{O}_{2}}$.

In the dog, Frowein et al. (1955) could not observe any significant changes in $\mathrm{CMR}_{\mathrm{O}_{2}}$ and $\mathrm{CBF}$ after the injection of $2-10 \mathrm{mg} / \mathrm{kg}$ chlorpromazine. $\mathrm{CMR}_{\mathrm{O}_{2}}$ in man (Fazekas et al., 1955; Morris et al., 1955; Aizawa et al., 1956; Moyer et al., 1956; Ehrmantraut et al., 1957; Sutherland et al., 1960) also, showed no changes under chlorpromazine. However, in the present study, the reduction in $\mathrm{CMR}_{\mathrm{O}_{2}}$ observed within 10 minutes after the injection of $0.5 \mathrm{mg} / \mathrm{kg}$ chlorpromazine continued throughout the period of observation. This reduction in $\mathrm{CMR}_{\mathrm{O}_{2}}$ lasted much longer than with the two other drugs. Cassano et al. (1965) demonstrated the distribution of chlorpromazine in cat brain using an autoradiographic technique and showed that retention of this agent in the cortex was reduced four hours later. Although many of the reports cited above are contrary to our findings, a possible explanation for this discrepancy could be the difference in the methods used for measuring CBF. The above-mentioned studies determined CBF by the nitrous oxide method of Kety and Schmidt (1948), while, in our study, CBF was determined by the direct measurement method described originally by Michenfelder et al. (1968). Theye and Michenfelder (1968) pointed out greater values for $\mathrm{CMR}_{\mathrm{O}_{2}}$ in their method than those generally observed in whole brain studies. The direct method is valid for a portion of the cerebral cortex, not the whole brain. Therefore, our findings indicate that chlorpromazine may reduce $\mathrm{CMR}_{\mathrm{O}_{2}}$ in the cortex and is in agreement with the results of electrophysiological studies by Gangloff and Monnier (1957), who demonstrated that chlorpromazine does affect the cerebral cortex.

The decrease in OGI observed with diazepam and chlorpromazine is due to disproportional change in $\mathrm{CMR}_{\text {glucose }}$ to a reduction in $\mathrm{CMR}_{\mathrm{O}_{2}}$. This was also suggestive in the chlorpromazine group at 10 minutes. Our findings showed that the changes in $\mathrm{CMR}_{\text {glucose }}$ were slower than those of $\mathrm{CMR}_{\mathrm{O}_{2}}$ at early states of their alteration. This delayed change in $\mathrm{CMR}_{\text {glucose }}$ was probably due to differences in equilibration of oxygen and glucose metabolism. Chlorpromazine produced a significant increase in $\mathrm{CMR}_{\text {glucose }}$ at five minutes. Aizawa et al. (1956) found an increase in $\mathrm{CMR}_{\text {glucose }} 30$ minutes after injection of chlorpromazine in man that was probably due to a rise in glucose level in the blood, but the blood glucose level was not mentioned. In the present study, a transitory but significant increase in $\mathrm{CMR}_{\text {glucose }}$ was not accompanied by an elevated blood glucose level. This finding is contrary to previous reports (Norman and Hiestand, 1955; Ryall, 1956; Bonaccorsi et al., 1964; Bachelard and Lindsay, 1966), which suggest hyperglycaemia with this drug. However, Norman and Hiestand (1955) found a profound species variation in hyperglycaemic response to chlorpromazine. At the present, it is difficult to evaluate the significance of the increase in $\mathrm{CMR}_{\text {glucose }}$ with chlorpromazine.

Changes in $\mathrm{CMR}_{\mathrm{O}_{2}}$ were paralleled by slow wave activities in the EEG (Fig. 1). During a period of reduction in $\mathrm{CMR}_{\mathrm{O}_{2}}$ by both diazepam and clomipramine, slow wave activities were predominant and returned to control levels when $\mathrm{CMR}_{\mathrm{O}_{2}}$ did. With chlorpromazine, however, an increase in slow wave activity was not so marked, whereas a decrease in fast wave activity was significant. Gleichmann et al. (1962) and Ingvar et al. (1962) demonstrated a correlation between cortical oxygen consumption and EEG pattern. The correlation which they found consisted of findings of predominant fast waves with high oxygen consumption and high voltage slow waves with low oxygen consumption. However, we found that chlorpromazine showed a different pattern of EEG changes from the other two drugs, even though there was considerably less reduction in $\mathrm{CMR}_{\mathrm{O}_{2}}$ than the other two; less pronounced slow wave activities. The reduction in CBF in the diazepam group was about the same magnitude as the reduction in $\mathrm{CMR}_{\mathrm{O}_{2}}$, agreeing with the finding that $\mathrm{PssO}_{2}$ remained unchanged. After administration of either 
clomipramine or chlorpromazine, CBF did not change significantly but roughly paralleled a reduction in $\mathrm{CMR}_{\mathrm{O}_{2}}$, resulting again in unchanged $\mathrm{PssO}_{2}$. Therefore, these changes in CBF seem to be mostly metabolic dependent.

From these results, it was concluded that diazepam and chlorpromazine are cerebral cortical metabolic depressants. This evidence suggests that the reduction in cerebral cortical oxygen consumption may play an important role in their therapeutic action in psychiatric patients.

The authors are grateful to Dr Hiroshi Takeshita, Department of Anesthesiology, Yamaguchi University, Japan, for his valuable advice and criticism throughout this study. We are also grateful to the publishers of Anesthesiology for permission to make use of some of the material used in Table 1.

\section{REFERENCES}

Aizawa, T., Gotoh, Y., Tazaki, Y., Hamaya, S., and Makino, K. (1956). The effects of chlorpromazine on cerebral circulation and metabolism. Keio Journal of Medicine, 5, 205-213.

Bachelard, H. S., and Lindsay, J. R. (1966). Effects of neurotropic drugs on glucose metabolism in rat brain in vivo. Biochemical Pharmacology, 15, 1053-1058.

Bonaccorsi, A., Garattini, S., and Jori, A. (1964). Studies on the hyperglycaemia induced by chlorpromazine in rats. British Journal of Pharmacology, 23, 93-100.

Cassano, G. B., Sjöstrand, S. E., and Hansson, E. (1965). Distribution of ${ }^{35} \mathrm{~S}$-chlorpromazine in cat brain. Archives Internationales de Pharmacodynamie et de Therapie, 156, 48-58.

Cohen, P. J., Alexander, S. C., Smith, T. C., Reivich, M., and Wollman, H. (1967). Effects of hypoxia and normocarbia on cerebral blood flow and metabolism in conscious man. Journal of Applied Physiology, 23, 183-189.

Davis, L. F., Gatz, E. E., and Jones, J. R. (1971). Effects of chlordiazepoxide and diazepam on respiration and oxidative phosphorylation in rat brain mitochondria. Biochemical Pharmacology, 20, 1883-1887.

Di Mascio, A., Heninger, G., and Klerman, G. L. (1964). Psychopharmacology of imipramine and desipramine: a comparative study of their effects in normal males. Psychopharmacologia, 5, 361-371.

Ehrmantraut, W. R., Shea, J. G., Ticktin, H. E., and Fazekas, J. F. (1957). Influence of promazine and methylphenidate on cerebral hemodynamics and metabolism. Archives of Internal Medicine, 100, 66-69.

Ernsting, M. J. E., Kafoe, W. F., Nauta, W. T., Oosterhuis, H. K., and Waart, C. de (1960). Biochemical studies on psychotropic drugs. 1. The effect of psychotropic drugs on $\gamma$-aminobutyric acid and glutamic acid in brain tissue. Journal of Neurochemistry, 5, 121-127.

Fazekas, J. F., Albert, S. N., and Alman, R. W. (1955). Influence of chlorpromazine and alcohol on cerebral hemodynamics and metabolism. American Journal of Medical Sciences, 230, 128-132.

Frowein, R. A., Hirsch, H., Kayser, D., and Krenkel, W. (1955). Sauerstoffverbrauch, Durchblutung und Vulnerabilität des Warmblütergehirns unter Megaphen (Chlorpromazin). Archiv für Experimentelle Pathologie und Pharmakologie, 226, 62-68.

Gangloff, H., and Monnier, M. (1957). Topic action of reserpine, serotonin, and chlorpromazine on the unanesthetized rabbit's brain. Helvetica Physiologica Acta, 15, 83-104.

Gleichmann, U., Ingvar, D. H., Lassen, N. A., Lübbers, D. W., Siesjö, B. K., and Thews, G. (1962). Regional cerebral cortical metabolic rate of oxygen and carbon dioxide, related to the EEG in the anesthetized dog. Acta Physiologica Scandinavica, 55, 82-94.

Ingvar, D. H., Lübbers, D. W., and Siesjö, B. K. (1962). Normal and epileptic EEG patterns to cortical oxygen tension in the cat. Acta Physiologica Scandinavica, 55, 210-224.

Kety, S. S., and Schmidt, C. F. (1948). The nitrous oxide method for the quantitative determination of cerebral blood flow in man: theory, procedure and normal values. Journal of Clinical Investigation, 27, 476-483.

Kleijn, E. van der (1969). Kinetics of distribution and metabolism of diazepam and chlordiazepoxide in mice. Archives Internationales de Pharmacodynamie et de Therapie, 178, 193-215.

Maekawa, T., Sakabe, T., and Takeshita, H. (1974). Diazepam blocks cerebral metabolic and circulatory responses to local anesthetic-induced seizures. Anesthesiology, 41, 389391.

Michenfelder, J. D., Messick, J. M., Jr, and Theye, R. A. (1968). Simultaneous cerebral blood flow measured by direct and indirect methods. Journal of Surgical Research, $8,475-481$.

Morris, G., Pontius, R., Herschberger, R., and Moyer, J. H. (1955). Cerebral hemodynamics following administration of chlorpromazine. (Abstract.) Federation Proceedings, 14, 371-372.

Moyer, J. H., Morris, G., Pontius, R., and Hershberger, R. (1956). Effect of chlorpromazine on cerebral hemodynamics and cerebral oxygen metabolism in man. Circulation, 14, 380-385.

Norman, D., and Hiestand, W. A. (1955). Glycemic effects of chlorpromazine in the mouse, hamster and rat. Proceed ings of the Society for Experimental Biology and Medicine. 90, 89-91.

Ryall, R. W. (1956). Some actions of chlorpromazine Journal of Pharmacology and Chemotherapy, 11, 339-345.

Sutherland, V. C., Burbridge, T. N., Adams, J. E., and Simon, A. (1960). Cerebral metabolism in problem drinkers under the influence of alcohol and chlorpromazine hydrochloride. Journal of Applied Physiology, 15, 189-196.

Theye, R. M., and Michenfelder, J. D. (1968). The effect of halothane on canine cerebral metabolism. Anesthesiology, 29, 1113-1118. 